\title{
Corrigendum: Polymorphisms in Genes Affecting Interferon- $\gamma$ Production and Th1 T Cell Differentiation Are Associated With Progression to Chagas Disease Cardiomyopathy
}

\section{OPEN ACCESS}

Approved by:

Frontiers Editorial Office,

Frontiers Media SA, Switzerland

${ }^{*}$ Correspondence:

Amanda Farage Frade-Barros amanda.frade@

universidadebrasil.edu.br

${ }^{\dagger}$ These authors have contributed equally to this work

Specialty section:

This article was submitted to Microbial Immunology, a section of the journal

Frontiers in Immunology

Received: 12 August 2020

Accepted: 12 August 2020

Published: 09 September 2020

Citation:

Farage Frade-Barros $A$, lanni BM, Cabantous S, Pissetti CW, Saba B, Lin-Wang HT, Buck P, Marin-Neto JA,

Schmidt A, Dias F, Hirata MH, Sampaio M, Fragata A, Pereira AC,

Donadi E, Rodrigues V, Kalil J, Chevillard C and Cunha-Neto E (2020)

Corrigendum: Polymorphisms in

Genes Affecting Interferon- $\gamma$

Production and Th1 T Cell

Differentiation Are Associated With

Progression to Chagas Disease

Cardiomyopathy.

Front. Immunol. 11:593759.

doi: 10.3389/fimmu.2020.593759

\begin{abstract}
Amanda Farage Frade-Barros ${ }^{1,2,3,4,5 *}$, Barbara Maria lanni ${ }^{1}$, Sandrine Cabantous ${ }^{3}$, Cristina Wide Pissetti ${ }^{6}$, Bruno Saba ${ }^{7}$, Hui Tzu Lin-Wang ${ }^{7}$, Paula Buck ${ }^{7}$, José Antonio Marin-Neto ${ }^{8}$, André Schmidt ${ }^{8}$, Fabrício Dias ${ }^{8}$, Mario Hiroyuki Hirata ${ }^{9}$, Marcelo Sampaio ${ }^{7}$, Abílio Fragata ${ }^{7}$, Alexandre Costa Pereira ${ }^{1}$, Eduardo Donadi ${ }^{8}$, Virmondes Rodrigues ${ }^{6}$, Jorge Kalil ${ }^{1,2,5}$, Christophe Chevillard ${ }^{10+}$ and Edecio Cunha-Neto ${ }^{1,2,4 t}$
\end{abstract}

\begin{abstract}
${ }^{1}$ Heart Institute (InCor), University of São Paulo School of Medicine (FMUSP), São Paulo, Brazil, ${ }^{2}$ Institute for Investigation in Immunology (iii), INCT, São Paulo, Brazil, ${ }^{3}$ Aix-Marseille Université, INSERM, GIMP UMR_S906, Marseille, France, ${ }^{4}$ Division of Clinical Immunology and Allergy, University of São Paulo School of Medicine, São Paulo, Brazil, ${ }^{5}$ Bioengineering Program, Instituto Tecnológico, Universidade Brasil, São Paulo, Brazil, ${ }^{6}$ Laboratory of Immunology, Universidade Federal Do Triângulo Mineiro (UFTM), Uberaba, Brazil, ${ }^{7}$ Laboratório de Investigação Molecular em Cardiologia, Instituto de Cardiologia Dante Pazzanese (IDPC), São Paulo, Brazil, ${ }^{8}$ School of Medicine of Ribeirão Preto (FMRP), University of São Paulo, Ribeirão Preto, Brazil, ${ }^{9}$ Department of Clinical and Toxicological Analyses, Faculty of Pharmaceutical Sciences, University of São Paulo (USP), São Paulo, Brazil, ${ }^{10}$ Aix Marseille Université, INSERM, TAGC Theories and Approaches of Genomic Complexity, UMR_1090, Marseille, France
\end{abstract}

Keywords: Chagas disease, cardiomyopathy, susceptibility, IL12, IL 10, IFN, IL4

\section{A Corrigendum on}

Polymorphisms in Genes Affecting Interferon- $\gamma$ Production and Th1 T Cell Differentiation Are Associated With Progression to Chagas Disease Cardiomyopathy

by Farage Frade-Barros, A. F., Ianni, B. M., Cabantous, S., Pissetti, C. W., Saba, B., Lin-Wang, H. T., et al. (2020). Front. Immunol. 11:1386. doi:10.3389/fimmu.2020.01386

In the original article, we neglected to include the funding from the National Institute of Health (P50 AI098461-02 and U19AI098461-06) to EC-N.

The authors apologize for this error and state that this does not change the scientific conclusions of the article in any way. The original article has been updated.

Copyright (c) 2020 Farage Frade-Barros, Ianni, Cabantous, Pissetti, Saba, Lin-Wang, Buck, Marin-Neto, Schmidt, Dias, Hirata, Sampaio, Fragata, Pereira, Donadi, Rodrigues, Kalil, Chevillard and Cunha-Neto. This is an open-access article distributed under the terms of the Creative Commons Attribution License (CC BY). The use, distribution or reproduction in other forums is permitted, provided the original author(s) and the copyright owner(s) are credited and that the original publication in this journal is cited, in accordance with accepted academic practice. No use, distribution or reproduction is permitted which does not comply with these terms. 